\title{
Bütünleşik Afet Riski Azaltımı ve İklim Değişikliğine Uyum Yaklaşımı Üzerine Bir Değerlendirme
}

\author{
Çiğdem TUĞAÇ 1
}

\section{Özet}

Küresel çapta son yıllarda yaşanan afetlerin sayı, sıklık ve şiddetinde önemli artışlar gözlemlenmektedir. Bu afetler içinde iklim değişikliğiyle ilişkili aşırı hava olaylarına bağlı meteorolojik ve hidrolojik afetlerin sayısındaki artış ise en fazla sayıda ve etki alanı en yüksek olandır. İklim değişikliğinin olumsuz sonuçlarının ülke sınırlarını aşan yapısı ve ekonomik, çevresel ve sosyal bağlamdaki etkileri, iklim ile ilişkilendirilen afetlerin beraberinde doğal, biyolojik ve teknolojik afetlerin de ortaya çıkmasını kaçınılmaz kılmaktadır. Bu afetlerden ise çoğunlukla toplumların en kırılgan kesimleri ve mücadele kapasitesi yeterli olmayan gelişmekte olan ülkeler daha fazla etkilenmektedir. Bu sorunlarla etkin bir biçimde mücadele edilmesinde günümüzde bütünleşik afet risk azaltımı ve iklim değişikliğine uyum yaklaşımının geliştirilmesine ilişkin çalışmalar giderek artmaktadır. Bu çalışmanın amacı, birbirinden bağımsız süreçlerde yürütülen afet riski azaltımı ve iklim değişikliğine uyum eylemlerine bütünleşik bir yaklaşım geliştirmenin ortaya çıkaracağı sonuçların değerlendirilmesidir. Çalışmada bütünleşik iklim değișikliğine uyum ve afet riski azaltımı yaklașımının kaynakların, idari ve beșerî kapasitenin etkin kullanılmasını, ölçek ekonomisi oluşturarak mali kaynakların doğru alanlara yönlendirilmesini sağlayacağı ve BM sözleşmelerinde ve belgelerinde yer alan hedeflerin gerçekleștirilmesi bağlamında önemli faydaları olduğu sonuçları elde edilmiştir.

Anahtar Kelimeler: Afet Riski Azaltımı, İklim Değişikliğine Uyum, Dirençlilik, Bütünleşik Yaklaşım, Sürdürülebilir Kalkınma

\section{An Evaluation on Integrated Disaster Risk Reduction and Climate Change Adaptation Approach}

\begin{abstract}
Significant increases are observed in the number, frequency and severity of disasters experienced in recent years globally. Among these disasters, the increase in the number of meteorological and hydrological disasters due to extreme weather events related to climate change is the most numerous and the most impact area. The nature of the negative consequences of climate change beyond the borders of the country and the effects in economic, environmental and social contexts make it inevitable that natural, biological and technological disasters occur along with disasters
\end{abstract}

\footnotetext{
${ }^{1}$ Dr., Şube Müdürü, İklim Değişikliği ve Uyum Dairesi Başkanlı̆̆ı, Çevre Yönetimi Genel Müd., Çevre ve Şehircilik Bakanlığı, Ankara e-posta/e-mail: cigdemtugac@gmail.com ORCID No: 0000-0002-2555-6641
}

Bu makaleye atıf yapmak için- To cite this article Tuğaç, Ç., (2021). Bütünleşik Afet Riski Azaltımı ve İklim Değişikliğine Uyum Yaklaşımı Üzerine Bir Değerlendirme. Afet ve Risk Dergisi, 4(1), 1-19. 
associated with climate. These disasters often affect the most vulnerable segments of societies and developing countries with insufficient fighting capacity. In order to tackle these problems effectively, studies on the development of integrated disaster risk reduction and adaptation to climate change are increasing. The purpose of this study is to evaluate the results of developing an integrated approach to disaster risk reduction and adaptation to climate change, which are currently carried out in independent processes. In the study, it has been concluded that the integrated climate change adaptation and disaster risk reduction approach will ensure efficient use of resources, administrative and human capacity, direct financial resources to the right areas by creating an economy of scale, and have significant benefits in achieving the goals of United Nations Conventions and documents.

Keywords: Disaster Risk Reduction, Climate Change Adaptation, Resiliency, İntegrated Approach, Sustainable Development

\section{GÍRIŞ}

Dünya Ekonomik Forumu (World Economic Forum-WEF) tarafından 2021 yılında yayımlanan raporda etki bakımından küresel çapta ön plana çıkan en önemli riskler; bulaşıcı hastalıklar, iklim eylemi konusunda başarısızlık, kitle imha silahları, biyoçeşitlilik kaybı ve doğal kaynak krizleri olarak ifade edilmiştir (WEF, 2021: 12). 2020 yılında Dünya Bankası ve Birleşmiş Milletler (BM) Afet Riski Azaltım Ofisi (UN Office for Disaster Risk Reduction-UNDRR) tarafından gerçekleştirilen çalışmalarda da iklim değişikliğine bağlı afetlerin, COVID-19 (Koronavirüs) pandemisinin ve ülkeler arasındaki çatışmaların yoksulluğun azaltılması doğrultusunda küresel çapta elde edilen onlarca yıllık kazanımların kaybedilmesine neden olabileceği vurgulanmıştır (UNDRR, 2020: 2; World Bank, 2020: xi).

BM tarafından gerçekleștirilen tüm çalışmalarda üzerinde önemle durulan husus, her alanda kimsenin geride bırakılmadığ politikalar geliştirilmesidir. Bununla birlikte çoğu kez bunun sağlanması mümkün olamamaktadır (UN, 2021; 1996). Özellikle toplumun yoksul kesimleri iklim değişikliğine bağlı afetlerden daha fazla etkilenmektedir (Busayo ve Kalumba, 2020: 1; The Cities Alliance vd., 2007: 8). BM 2030 Gündemi ve Sürdürülebilir Kalkınma Amaçları'nın (SKA) (Şekil1) ilki olan SKA1-Yoksulluğa Son Verilmesi'nde belirtildiği șekliyle; 'aşırı yoksulluk (extreme poverty)' yaşayan nüfus, "günde 1,25 dolardan daha az parayla geçinen insanların sayısı" olarak tanımlanmıştır (UNDP, 2020a). Küresel çapta kentlerde bu tanıma uyan kent yoksullarının oranının giderek artmakta olduğu görülmektedir. BM Habitat rakamlarına göre, kentsel alanlarda gecekondularda ve yasal olmayan yerleşimlerde yaşayan kişi sayısı 1990 yılında küresel çapta 650 milyon kişi iken, günümüzde yaklaşık bir milyar kişiye (Şekil 2) ulaşmıştır (UN Habitat, 2020). Kentlerde altyapı ve temel servislere erişimdeki güçlükler sağlık sorunlarını ortaya çıkartmakta, bu durum özellikle kentlerdeki yoksul kesimlerde yaygın şekilde görülmektedir. Kentlerin bu bölümleri genellikle yetersiz altyapılara bağlı olarak, iklim değişikliği başta olmak üzere çeşitli nedenler sonucu ortaya çıkan afetlerden en çok etkilenen yerler olmaktadır. Yaşadıkları kırsal alanlardaki işsizlik, çevresel bozulma, çatışmalar ve afetler gibi sorunlar neticesinde kentlere göç eden nüfus her geçen gün artmaktadır. 2019 yılında yaşanan afetler ve çatışmalar nedeniyle 33,4 milyon kişi göç etmek zorunda kalmıştır (Anzellini vd., 2020: 1; IOM, 2010).

Hükümetlerarası İklim Değişikliği Paneli (Intergovernmental Panel on Climate Change-IPCC) tarafından, iklim değişikliğine bağlı aşırı hava olaylarının ve afetlerin ekonomik kalkınma oranını düşürmesiyle, özellikle gelişmekte olan ülkelerin kentlerinde yeni yoksulluk alanlarının oluşacağı öngörülmektedir. Bu kapsamda iklim değişikliğiyle mücadele edilmesi yönünde uygun sera gazı azaltımı ve iklim değişikliğine uyum (IDU) politikalarının tespit edilmesi ve iklim değişikliğine karşı dirençliliğin sağlanmasında afet riski azaltımı (ARA) eylemleri ile birlikte ele alınmaları oldukça önemlidir (IPCC, 2014a). 

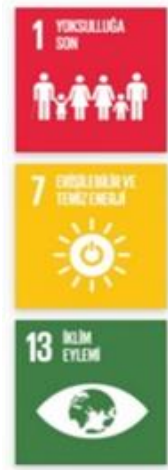
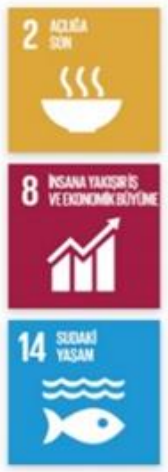
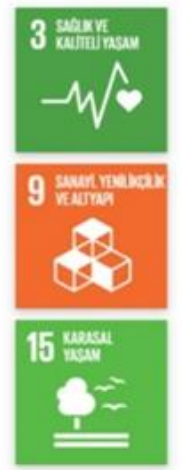
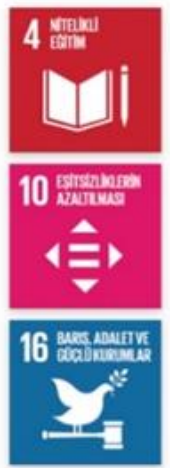
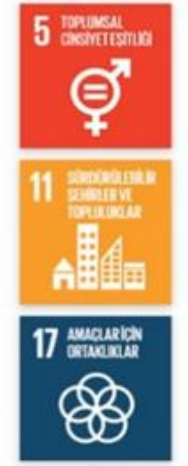

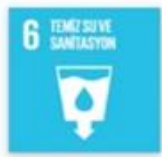

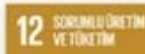

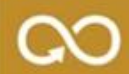

\section{(7)}

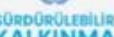

KALKINMA

Şekil 1. BM Sürdürülebilir Kalkınma Amaçları (UNDP, 2020b)
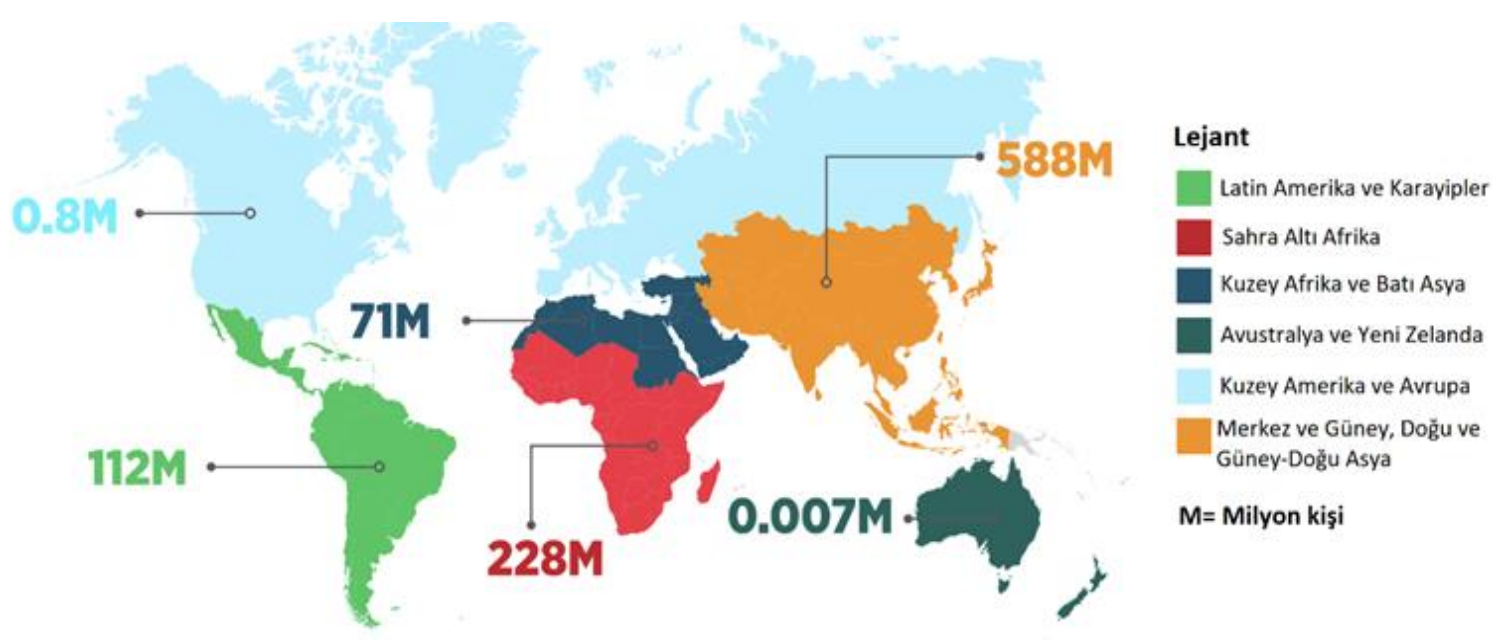

Şekil 2. Küresel çapta gecekondular ve yasal olmayan yerleşimlerde yaşayan nüfus miktarı-2016 (UN Habitat, 2020: 21)

IPCC'nin $1,5^{\circ} \mathrm{C}$ Küresel Isınma Özel Raporu'nda küresel ortalama sıcaklık artışının endüstri öncesi seviyelere göre $1,5^{\circ} \mathrm{C}$ ile sınırlandırılmasının $2^{\circ} \mathrm{C}^{\prime}$ lik ısınmaya kıyasla sürdürülebilir kalkınma bağlamında pek çok hedefe ulaşılmasını kolaylaştıracağı ve dirençliliğin sağlanması, yoksulluğun ve eşitsizliklerin azaltılması konularında daha başarılı sonuçlar elde edilmesini sağlayacağı belirtilmiştir. Buna göre iklim değişikliğiyle mücadele edilmesi yönünde alınacak tedbirlerle yoksulluk karşısında kırılgan olan ve iklim riskleriyle karşı karşıya bulunan kişilerin sayısının 62457 milyon kişi kadar azaltılabileceği öngörüsünde bulunulmuş ve bu sayede özellikle dünyanın en az gelişmiş ve gelişmekte olan ülkelerinde yaşayan yoksulların su ve gıda güvenliklerinin sağlanması yanında, sağlık sorunları ve ekonomik kayıp yașama risklerinin azaltılması konusunda önemli kazanımların elde edilebileceğinin altı çizilmiştir (IPCC, 2018a).

Günümüzde iklim duyarlı politikaların, yeniliklerin ve teknolojilerin geliştirildiği pek çok sektörde, bir yandan sürdürülebilir ve düşük karbonlu kalkınma doğrultusundaki hedefleri gerçekleștirmeye dönük önemli adımlar atılırken; bir yandan da sera gazı emisyonlarının azaltılması, İDU kapasitesinin arttırılması ve afet risklerine karşı kırılganlıkların azaltılması doğrultusunda da önemli kazanımlar elde edildiği görülmektedir. Ancak bunların başarılmasında iklim değişikliğiyle mücadele kapsamında özellikle İDU ve ARA eylemlerinin bütünleşik bir biçimde ele alınması giderek daha fazla önem kazanmaktadır (Lisa ve Schipper, 2011: 16; Prasad vd., 2009: 17). BM tarafından da 2030 Gündemi ve SKA'lar kapsamında tespit edilen hedeflere ulaşılmasında yerleşimlerde dirençliliğin sağlanmasının ön koşul olduğu ve bunun için de ARA ve 
İDU eylemlerinin bütünleşik bir biçimde ele alınmasının elzem olduğu ifade edilmiştir (UNDRR, 2020: 7).

Bu esaslar doğrultusunda bu çalışmanın amacı, günümüzde birbirinden bağımsız süreçlerde ele alınan ARA ve IDU eylemlerinin bütünleşik bir yaklaşımla ele alınmasının ortaya çıkaracağı sonuçların değerlendirilmesidir. Bu kapsamda çalışma iki bölüm halinde ele alınmıştır. (1) Öncelikle kavramsal çerçeve tanımlanmış ve bu kapsamda iklim değişikliği, İDU, ARA ve ilişkili kavramlar incelenmiştir. (2) Ardından, önceki bölümde yer verilen kavramsal çerçeve üzerinden IDU ve ARA eylemlerinin ne şekilde bütünleşik bir yaklaşımla ele alınabileceği, bu kapsamda karşılaşılabilecek güçlükler ve iki yaklaşımın ortak noktaları irdelenmiş ve söz konusu bütünleşik yaklaşımın geliştirilmesinde BM tarafından önemli bir araç olarak değerlendirilen Ulusal Uyum Planları ve bu planlara ilişkin süreçler incelenmiştir. Bu bölümlerden elde edilen bulgular ise Sonuç kısmında bir arada değerlendirilmiştir.

Çalışma yöntemi olarak ilişkisel araştırma modeli kullanılmıştır. İDU ve ARA eylemlerinin bütünleşik biçimde ele alınması ile dirençliliğin sağlanması arasındaki ilişkinin kurulması hedeflenmiştir. Çalışmada farklı kaynakların yanı sıra, BM'nin, Dünya Bankası'nın ve IPCC'nin raporlarından, bilimsel ve istatistikî verilerinden yararlanılmış ve bunların yanı sıra diğer uluslararası literatür de veri ve kaynak materyali olarak değerlendirilmiştir.

\section{KAVRAMSAL ÇERÇEVE}

Dirençlilik (resiliency), bir sistemin ya da topluluğun şoklar ve streslere maruz kalması karşısında risk yönetimi aracılığıla temel yapı ve fonksiyonlarını sürdürerek ve gerekli koruma ve yenilemeyi de içerecek biçimde zamanında ve etkin bir şekilde dayanıklılık gösterme, absorbe etme, uyum ve dönüşüm süreçlerinden geçmesini ifade etmektedir (UNDRR, 2015: 2). Dirençliliği etkileyen ve afetlerin oluşumunda önemli paya sahip olan iklim değişikliği ise (IPCC, 2014b: v; Islam vd., 2020: 255), Birleşmiş Milletler İklim Değişikliği Çerçeve Sözleşmesi'nde (BMIDDÇS) "uzun süre boyunca iklimde gözlenen doğal değişimler ile doğrudan ya da dolaylı olarak insan faaliyetlerinin neticesinde ortaya çıkan ve küresel atmosferin kompozisyonunu bozan değişiklik" olarak tanımlanmaktadır (UNFCCC, 1992, s.7).

İklim değişikliğine neden olan sera gazları IPCC tarafından karbondioksit (CO2), metan (CH4), su buharı (H2O), nitözoksit (N2O), ozon (O3), hidroflorokarbonlar, perfulorakarbonlar, kükürt heksaflörür olarak kabul edilmektedir. Esasen bu gazlar atmosferde doğal olarak bulunmaktadır ve yerkürenin canlıların yaşamasına olanak sağlayacak sıcaklıkta kalmasını sağlamaktadır (IPCC, 2018b). Ancak özellikle kentlerde gerçekleștirilen insan faaliyetleri, söz konusu sera gazlarının atmosferdeki miktarını arttırmaktadır ve ortaya çıkan sera etkisi (greenhouse effect) sonucunda dünyanın normal koşullara göre daha fazla ısınması ile iklim değișikliği meydana gelmektedir (IPCC, 2018a; UNFCCC, 2015).

İklim değiş̧ikliği ile mücadelede sera gazı azaltımı (mitigation) ve uyum (adaptation) eylemleri, Paris İklim Anlaşması'nda da vurgulandığı gibi eşit derecede önemli iki stratejidir (UNFCCC, 2015). Azaltım eylemlerinde temel amaç küresel iklim değişikliğine neden olan sera gazı emisyonlarının azaltılmasıdır. İDU ise IPCC tarafından "insan sistemlerinin iklim değişikliğinin gerçekleşen ve beklenen etkilerinden daha az zarar görmesini ya da bu etkilerden yararlanmasını sağlamak üzere yapılacak düzenlemeler" olarak tanımlanmaktadır (IPCC, 2018b: 2).

IPCC'nin 2014 yılında yayımladığı 5. Değerlendirme Raporu'nda ilk kez \%95 kesinlik oranı ile çağımızda yaşanan iklim değişikliğinin kaynağının insan faaliyetleri olduğu ve özellikle 1950'li yıllardan bu yana gözlemlenen etkilerin son bin yılda eşi görülmemiş nitelikte olduğu ifade edilmiştir. Rapor'da da vurgulandığı gibi insan faaliyetleri doğal kaynakların üzerinde önemli bir 
baskı oluşturmaktadır ve bu faaliyetlerin iklim sistemi üzerinde ortaya çıkarttığı etkiler, yaygın ve geri döndürülemez niteliktedir. IPCC tarafından ayrıca iklim değișikliğinin olumsuz sonuçlarının ekosistemleri ve insanları sayı, sıklık ve şiddeti artan ısı dalgaları, fırtınalar ve tayfunlar gibi aşırı hava olayları sonucu oluşan afetlere karşı daha kırılgan hale getirmiş olduğu vurgulanmıştır (IPCC, 2014a: 538; IPCC, 2014b: v). Bu ise tehlike (hazard), maruziyet (exposure) ve kırılganlığın (vulnerability) bir araya gelerek (Şekil 3) afet risklerini oluşturmasına neden olmaktadır (UNDRR, 2020: 10). Oysa insan eylemleri sonucu zarar gören ekosistemler, insanların afetlere karşı korunmaları ve afetler sonrasında iyileşmenin sağlanabilmesi için kritik öneme sahip servisler sunmaktadır (Munang, 2013: 47; Warner vd., 2009: 1).

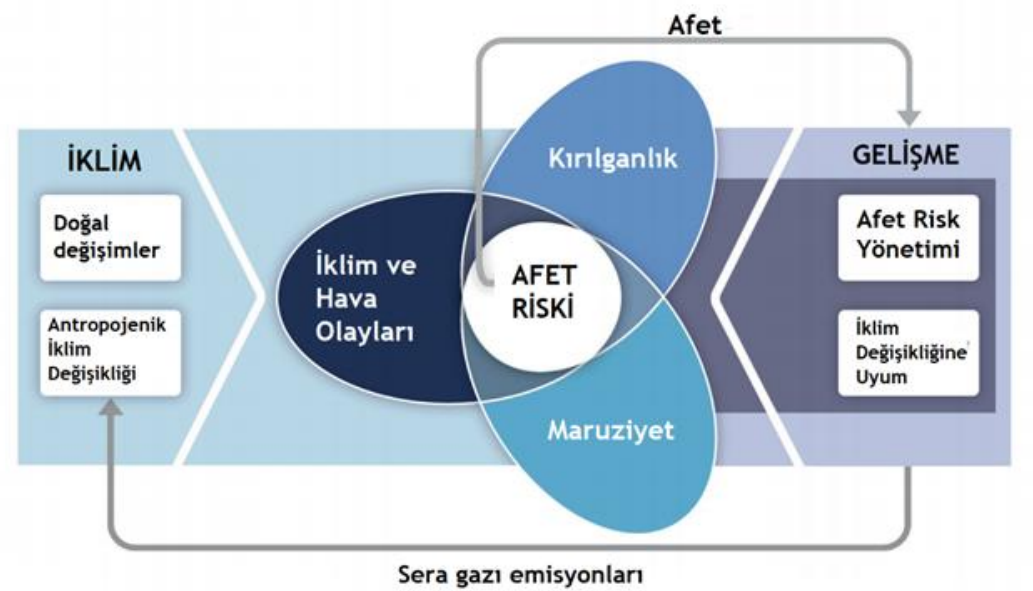

Şekil 3. Uyum, sürdürülebilir kalkınma ve afet riski azaltımı ilişkisi (IPCC, 2012: 4)

IPCC'nin yapmış olduğu tanımlamaya göre afet; "Bir topluluğun veya toplumun normal işleyişinde, kırılgan sosyal koşullar ile etkileşimde bulunan tehlikeli fiziksel olaylar nedeniyle yaygın insani, ekonomik veya çevresel etkiler ortaya çıkaran ve kritik insan ihtiyaçlarını karşılamak için acil durum müdahalesi ve kurtarma için harici destek gerektirebilen şiddetli değişikliklerdir". Afet riski ise, IPCC tarafından "Belirli bir süre boyunca bir topluluğun veya toplumun normal işleyişinde kırılgan sosyal koşullar ile etkileşimde bulunan tehlikeli fiziksel olaylar nedeniyle yaygın insani, ekonomik veya çevresel etkiler ve kritik insan ihtiyaçlarını karşılamak için acil durum müdahalesi ve kurtarma için harici destek gerektirebilen ciddi değişiklikler ortaya çıkma olasılığı" olarak tanımlanmaktadır (IPCC, 2012: 5).

ARA, mevcut afet risklerinin azaltılmasını ve yenilerinin önlenmesini amaçlamaktadır. Bu sayede dirençlilik artırllabileceği gibi sürdürülebilir kalkınma da mümkün olabilecektir. UNDRR tarafından ARA, afet risk yönetiminin politika hedefi olarak tanımlanmaktadır. Afet risk yönetimi ise; ARA politika ve stratejilerinin yeni afet risklerin önlenmesi, mevcut afet risklerinin azaltılması, dirençliliğin güçlendirilmesi ve afetlere bağlı kayıpların azaltılması doğrultusunda uygulanması olarak tanımlanmıştır (UNDRR, 2020: 8).

UNDRR tarafından yapılan sınıflandırmada afetleri ortaya çıkaran tehlikeler; (1) doğal tehlikeler (fırtınalar, tropik siklonlar, seller, toprak kaymaları, yangınlar, tsunamiler, depremler, kuraklık, ıSı dalgaları, ani hava soğumaları, volkanik aktiviteler), (2) biyolojik tehlikeler (enfeksiyon hastalıkları, zehirleyici maddeler, bitki ve böcek enfeksiyonları, insan-hayvan çatışmaları, çeşitli maddeler, istilacı türler), (3) teknolojik tehlikeler (kimyasallarla, nükleer, radyolojik ve atıklarla ilişkili kazalar, ağır metaller ile kirlenme ve siber tehlikeler), (4) iklim değişikliğine bağlı aşırı hava olayları (extreme events) (tayfunlar, aşırı yağışlar vb.) ve yavaş gelişen hava olayları (slow onset events) (okyanuslarda asitleşme, deniz seviyesinde yükselme, sıcaklık artışı, çölleşme, tuzlanma) olarak ifade edilmektedir. Söz konusu tehlikeler sonucu ortaya çıkan afetler, çok sayıda insanı, ekosistemleri ve ekonomiyi ciddi biçimde etkilemektedir (UNDRR, 2020: 6, 12). 
BM Habitat tarafından da iklim değişikliği projeksiyonlarının ortaya koyduğu sonuçların özellikle kentlere etkisi değerlendirilerek; iklim ile ilişkili risklere ve iklim değişikliğine bağlı aşırı hava olaylarına karşı hazırlıklı olunmasının önemi vurgulanmaktadır. Bu doğrultuda BM Habitat tarafından, Yeni Kentsel Gündem'de (New Urban Agenda) ortaya konulan ve sürdürülebilir kalkınmanın sağlanması yönünde tespit edilen ilkelerin hayata geçirilmesinde, doğal ve insan kaynaklı afetler ve iklim değişikliği ile ilişkili afet riskleri konusunda önlemler alınmasının önemli olduğu belirtilmiștir (UN Habitat, 2020: 8; 2016). 2020 yılında UNDRR tarafından yayımlanan raporda, 2000-2019 yılları arasında meydana gelen afetlerde \%91'lik paya sahip iklim ile ilişkili afetlerde son yıllarda önemli artış gözlemlendiği ve bu afetlerde 1,23 milyon insanın hayatını kaybetmesine neden olduğu olduğu ifade edilmiştir (UNDRR ve CRED, 2020: 8).

IPCC'nin $1,5^{\circ} \mathrm{C}$ Küresel Isınma Özel Raporu'nda mevcut eğilimlerin sürmesi durumunda 2100 yılında küresel ortalama sıcaklıklardaki artışın $3^{\circ} \mathrm{C}$ civarında gerçekleșeceği vurgulanmaktadır (IPCC, 2018a). UNDRR ise bu miktardaki sıcaklık artışının potansiyel şiddetli etkilere sahip afetlerin gerçekleşme sıklığını artıracağını belirtmekte ve ulusal ve yerel düzeyde ARA ve İDU stratejilerinin geliştirilmesi gerektiğini ifade etmektedir (UNDRR ve CRED, 2020: 7).

Özetle; insanlar tarafından gerçekleştirilen faaliyetlerde ve yatırımlarda afet risklerinin yeterince iyi değerlendirilememesi, yukarıda ifade edilen etkileri şiddetlendirmekte ve böylelikle tehlike ve risklere karşı maruziyet oranı artarak, beraberinde ekonomik, sosyal, çevresel dirençlilik sorunları ortaya çıkartmaktadır. İklim ve afet risklerine karşı dirençliliğin sağlanmasında toplumun tüm kesimlerinin farkındalığının artırılması ve teknik, finansal ve idari kapasitenin geliştirilmesi bu nedenle elzemdir. İDU ve ARA süreçlerinin bütünleşik bir yaklaşımla bir arada ele alınmasının, dirençliliğin sağlanması ve diğer alanlarda ortaya çıkardığı sonuçlar bir sonraki başlıkta ele alınmıştır.

\section{BÜTÜNLEŞİK ARA VE İDU YAKLAŞIMI}

2015 yılında BMİDÇS 21. Taraflar Konferansı sonucunda kabul edilen Paris İklim Anlaşması'nın temel hedefi olan küresel ortalama sıcaklıkların $2^{\circ} \mathrm{C}$ altında tutulması ve $1,5^{\circ} \mathrm{C}$ ile sınırlanması konusunda çaba göstermek doğrultusunda tüm dünyada çeşitli çalışmalar yapılmaktadır. İklim değiş̧ikliği habitatlarda ve ekosistemlerde önemli değişimler ve aşırı hava olaylarında artışlar meydan getiren bir 'tehdit çarpanı'dır (threat multiplier) ve IPCC'nin $1,5^{\circ} \mathrm{C}$ Küresel Isınma Özel Raporu'nda da bu konu üzerinde durularak; dünyanın iklim değișikliğinin olumsuz etkilerinden giderek daha fazla etkileneceği vurgulanmıștır (UNFCCC, 2015; IPCC, 2018a). Bu bakımdan Paris Anlaşması doğrultusunda tüm ülkelerin düşük karbonlu, iklim dirençli ekonomilere geçişi elzem bir husus olarak ele alınmaktadır ve ülkelerden bu ortak amaç etrafında kendi ulusal koşulları çerçevesinde katkı vermeleri (Ulusal Olarak Belirlenmiş Katkılar- Nationally Determined Contributions- NDCs) ve İDU konusuna sera gazı azaltımı kadar önem vermeleri istenmiştir (UNFCCC, 2017: 5).

İDU aynı zamanda BM 2030 Gündemi'nde yer alan 17 SKA'daki 169 hedef ile ilişkilidir ve sürdürülebilir kalkınmanın sağlanması açısından önemli bir husus olarak görülmektedir. SKA'lar kapsamında SKA13 doğrudan İklim Eylemi’ne ilişkindir (UNDP, 2020b).

Sendai Afet Riski Azaltım Çerçevesi ise kendisinden önce gelen Hyogo Eylem Çerçevesi ile aynı esaslar doğrultusunda yedi hedef ve dört öncelikli eylem kapsamında pek çoğu iklim değişikliği tarafından daha şiddetli hale getirilen, yoğunluk ve sıklı̆̆ artan afetlerin sürdürülebilir kalkınmayı sekteye uğrattığını vurgulamaktadır. Sendai Çerçevesi'nin önemi afetlerle mücadeleden, mevcut ve olası risklerle mücadele sürecine geçilmiş olması ve dirençliliğin oluşturulmasını hedeflemesidir. Bu kapsamda ülkelerden; (1) afet risklerini anlamaları, (2) afet risk yönetişimini güçlendirmeleri, (3) afetlerin azaltılması için dirençliliğe yatırım yapmaları ve 
(4) afetlere daha iyi cevap verilebilmesi, afet sonrasında rehabilitasyon süreçlerinde "eskisinden daha iyi duruma gelinmesi (build back better) ve yeniden yapılanma bağlamlarında hazır olmaları istenmektedir. Bu sayede afet risklerinde ve can kayıplarında kademeli bir azalma olacağı gibi; bireylerin, özel sektörün, toplulukların ve ülkelerin çevresel, kültürel, sosyal, fiziksel ve ekonomik varlıklarının sürdürülmesi de mümkün olabilecektir. Sendai Afet Riski Azaltım Çerçevesinde küçük ölçekli ve büyük ölçekli, sık ve sık olmayan, ani ve yavaş gelişen afetler, doğal veya insan yapımı olmalarına ve en az bunun kadar çevresel, teknolojik ve biyolojik kaynaklı riskler olmalarına göre ele alınmaktadırlar (Guralnick, 2018; NAP Community, 2019; UNDRR, 2015; UNFCCC, 2017: 8).

Söz konusu risklerle mücadelede İDU ve ARA eylemlerinin bütünleşik bir biçimde ele alınmasına ilişkin yaklaşım uluslararası alanda 2000'li yıllarla birlikte üzerinde çalışılmaya başlanan bir konu olmuştur. Bu kapsamda Uluslararası Kızılhaç Örgütü, Uluslararası Afet Risk Azaltımı Stratejisi (International Strategy for Disaster Reduction-ISDR) ve BMIDÇS gibi sayıları artırılabilecek pek çok uluslararası kuruluş tarafından çalışma grupları oluşturulmuştur (Birkmann ve Von Teichman, 2010: 173).

Söz konusu uluslararası çabalara rağmen, her iki yaklaşım kapsamında yapılan çalışmaların bugüne kadar iki ayrı başlıkta birbiri ile ilişkilendirilmeden geliştirildikleri görülmektedir. Oysa iki yaklaşım da iklim sistemi, doğal, biyolojik tehlikeler, bunların insanlara, ekosistemlere etkisi gibi pek çok başlıkta önemli bir içerik, birikim ve uzmanlık barındırmaktadır (Forino vd., 2014: 474; Solecki vd., 2011: 138).

BMİDÇS ve UNDRR tarafından da söz konusu birikimin birlikte değerlendirilmesinin dirençliliğin sağlanması, kırılganlıkların azaltılması, BM SKA'larının hedeflerine ulaşılması bağlamında önemli avantajları beraberinde getireceği (Şekil 4) vurgulanmaktadır. Ancak BMIDÇS uzman toplantılarında söz konusu bütünleşmenin kapsamının tamamen birleştirme değil, kısmi ama sağlam politika bütünleşmesi şeklinde olması gerektiği üzerinde durulmaktadır. Bu sayede bütünleşik politikaların takibi daha iyi bir biçimde yapılabilecektir (Islam vd., 2020; UNDRR, 2020: 8; UNFCCC, 2017: 8).

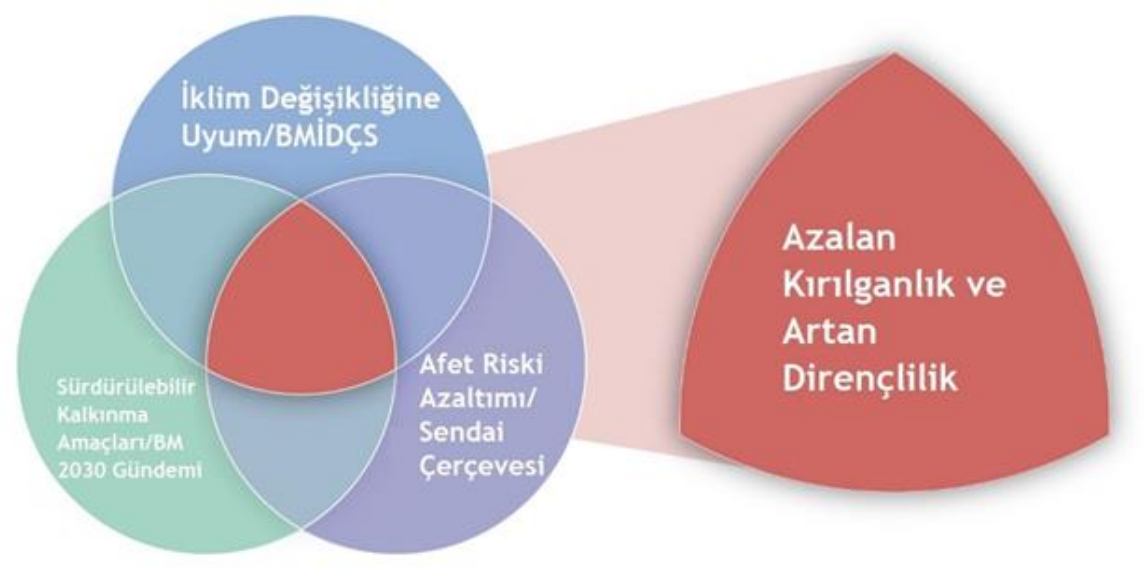

Şekil 4. Bütünleşik BM SKA, Sendai ve BMİDÇS yaklaşımı (UNFCCC, 2017)

2017 yılında BMIDÇS kapsamında Bonn'da yapılan Uyum Teknik Uzmanlar Toplantısı sonucunda kabul edilen FCCC/TP/2016/nolu dokümana dayalı olarak hazırlanan Teknik Kâğıt'da Sendai Afet Riski Azaltım Çerçevesi kapsamında ARA, BMIDÇS kapsamında İDU ve BM 2030 Gündemi kapsamında BM SKA'ları arasındaki sinerjinin sunduğu olanaklar ve avantajlar ele alınmıştır. Buna göre söz konusu sinerjinin sağlanması (UNFCCC, 2017), 
- Toplumsal ölçekte dirençliliğin sağlanması, maliyet etkin çözümler sunulması, etkinliğin arttırılması ve uyum eylemlerinin hayata geçirilmesi bağlamında faydalıdır.

- Farklı düzeydeki paydaşlar arasında koordinasyon sağlanması açısından yararlıdır ancak iş birliğinin sağlanmasında tüm paydaşların sorumluluklarının ve rollerinin açık bir biçimde tanımlanması gereklidir.

- IDU eylemleri, sürdürülebilir kalkınma ve ARA kapsamında belirli ortak temalar, ölçekler ve hedefler içermektedir. Hem dirençlilik hem de ekosistem kavramları bütünleşik yaklaşım geliştirilmesinde odak kavramlar olarak ele alınmalıdır.

- Bu kavramların birbiriyle ilişkilendirilmesinde farklı ölçeklerde, farklı sektörlerde ve farklı paydaşlar arasında politika oluşturmak, bütünleștirmek ve bundan fayda sağlamak bağlamında oldukça elverişli bir ortam söz konusudur.

- Özellikle uyum ve afetlerin yerele özgü doğası bu kapsamda sadece merkezi yönetimin değil, yerel toplulukların da süreçlere dâhil olmasını ve yerele özgü çözüm önerilerini sunmasına yardımcı olan bir çoklu politika geliştirme sürecini teşvik etmektedir.

- Söz konusu süreçlerin bütünleştirilmesi, veri temini ve bu verilerin etkin kullanımında olumlu sonuçlar ortaya koymaktadır.

- Sürdürülebilir kalkınma doğrultusunda İDU ve ARA süreçlerine bütünleşik yaklaşımda en önemli araçlardan biri Ulusal Uyum Planlarının (UUP) (National Adaptation Plans-NAPs) hazırlanması ve uygulanmasıdır.

- Sürdürülebilir kalkınma ve iklim değişikliğine uyum ve afet riski azaltımı süreçlerinde başarıya ulaşılmasında uluslararası iş birliği önemlidir. Bu iş birliğinin kapsamında teknoloji transferi, kapasite geliştirme ve finansal yardımların olması elzemdir.

Uluslararası alanda yapılan pek çok çalışmada ARA ve İDU süreçlerinin bütünleşik olarak ele alınması konusunda bir uzlaşı olmasına rağmen, söz konusu süreçlerin bütünleşik olarak ele alınmasında karşılaşılan bazı temel güçlükler olduğu görülmektedir. Bu güçlükler aşağıdaki gibi gruplandırılmaktadır (Birkmann ve Von Teichman, 2010: 172):

- IDU ve ARA konularında tüm ölçeklerde farklı çalıșmaların yapılması ve bunlar arasında koordinasyonun sağlanamaması,

- Genellikle ülkelerde IDU ve ARA konularında farklı idari yapılanmaların söz konusu olması,

- İDU ve ARA eylemlerine dönük olarak yeterli ve uygun finansal kaynakların bulunmaması,

- İklim değişikliğinin yerel etkileri konusunda yeterli ve güvenilir verilerin temin edilmesi konusunda eksikliklerin söz konusu olması.

Bütün bu güçlüklere rağmen, İDU ve ARA süreçlerinin yapısına bakıldığında esasen birbirini tamamladıkları görülmektedir. ARA, hidrolojik, meteorolojik ve jeofizik tehlikeler de dâhil olmak üzere tüm tehlike tiplerini kapsarken, İDU, iklim ile ilişkili tehlikeler konusuna yoğunlaşmaktadır. ARA, ağırlıklı olarak afetlere yol açan aşırılıklara odaklanırken, İDU, ortalama iklim koşullarındaki değişiklikleri ve bunun sağlayabileceği faydaları ele almaktadır. Dolayısıyla IDU ve ARA konularındaki yaklaşımların sürdürülebilir kalkınma ilkesi de gözetilerek bütünleşik biçimde ele alınmasında dirençliliğin tüm boyutlarının kapsanması bağlamında büyük yarar vardır (Mercer, 2010: 247; Thomalla vd., 2006: 40; UNICEF ve AIDMI, 2016: 2). Bu iki yaklaşımın bir arada ele alınmasında yaşanan ve yukarıda belirtilen güçlüklerin aşılmasında ise sorunların giderilmesine faydalı olabilecek ortaklıkların bulunması önemlidir. Bu kapsamda UNFCCC Uyum Uzmanlar grubu tarafından belirlenen ortaklıklar ise şunlardır (UNFCCC, 2017: 15): 
- Ortak temalar: Dirençlilik ve ekosistemler

- Ortak ölçekler: Çok ölçeklilik ve çok sektörlülük

- Ortak hedefler: Etkilenen insanlar ve topluluklar

- Politika bütünleşmesini geliştirme firsatları.

Yukarıda da açıklandığı gibi iklim değişikliğine bağlı afetler, özellikle toplumun kırılgan kesimlerini ve küresel çapta bakıldığında da dünyanın en az gelişmiş ülkelerinin yer aldığı bölgeleri en fazla etkilemektedir (Davies vd., 2009: 1). Bu ülkelerin iklim değişikliğine uyum kapasitelerinin gelişmiş olmamasının yanında, afetlerin yaşanma sayı ve sıklığı da yine bu ülkelerde fazladır ve ekosistemlerinin ve gıda üretim zincirlerinin zarar görmesi kıt kaynaklar için mücadeleyi arttıran bir husustur. Bu ise beraberinde küresel çapta etkileri olan göçleri ve ulusal ve uluslararası güvenlik sorunlarını ortaya çıkarmaktadır (Santoalla, 2010; IOM, 2010; UNDRR, 2020: 9).

BMİDÇS kapsamında gelişmiş ülkelerin gelişmekte olan ülkelere finansal destek, teknoloji transferi ve kapasite geliştirme destekleri vermelerine ilişkin temel sorumlulukları tanımlanmıştır ve yukarıda da vurgulandığı gibi bu sorumlulukların yerine getirilmesi ve afet riskleriyle mücadelede edilmesinde BM tarafından UUP'ları önemli bir araç olarak görülmektedir (UNFCCC, 2021). UUP sürecinin (Şekil 5) amacl, iklim değiş̧ikliğinin etkilerine karşı uyum kapasitesinin ve dirençliliğin arttırılması suretiyle afet risklerine karşı kırılganlığın azaltılmasıdır. Bunun yanı sıra BMIDÇS Taraflar Konferansı'nın 5/CP.17 sayılı kararının 1. paragrafı uyarınca ilişkili tüm sektörlerde ve farklı ölçeklerde gerçekleştirilen İDU'ya ilişkin çalışmaların mevcut ve yeni oluşturulan politikalarla, program ve aktivitelerle ve gelişim planlaması süreci ve stratejileriyle ile bütünleştirilmesi de amaçlanmaktadır (UNFCCC, 2011).

BMİÇS'nin Yükümlülükleri açıklayan 4. maddesinin 1(b) fikrasında bütün Tarafların iklim değişikliğine uyumu kolaylaştıracak önlemleri almakla yükümlü oldukları ifade edilmiștir. Aynı maddenin 1(e) fıkrasında; Taraf Ülkelerden iklim değişikliğinin etkilerine uyum hazırlıklarında iş birliği yaparak kıyı alanlarının yönetimi, su kaynakları ve tarım ve özellikle kuraklık, çölleşme ve sellerden etkilenen alanların korunması ve rehabilitasyonu için uygun ve bütünleşik planlar hazırlamaları ve geliştirmeleri istenmektedir (UNFCCC, 1992).

BMIDÇS kapsamında 2010 yılında Kankun'da gerçekleștirilen 16. Taraflar Konferansı'nda İDU konusunda önemli kararlar alınmıştır (Karar 1/CP.16). Bunlar (UNFCCC, 2010);

- Kankun Uyum Çerçevesi (1/CP.16, para.13) ile Uyum Komitesi'nin (1/CP.16, para.20) kurulması,

- Kayıp ve zararlara (loss and damages) ilişkin bir İş Planı oluşturulması (1/CP.16, para.26)

- En az gelişmiş ülkelerin (EAGÜ) UUP'larını geliştirerek uygulamaya almaları için bir mekanizma oluşturulması (1/CP.16, para.15),

- EAGÜ’ler dışında kalan gelişmekte olan ülkelerin de kendi UUP’larını destekleyici yaklaşımlar geliştirmesi, (1/CP.16, para.16)

- Gelişmiş ülkelerin bunları gerçekleştirebilmeleri için gerekli olan finansal, teknolojik ve kapasite geliştirme desteklerini gelişmekte olan ülke taraflarına sunmaları (1/CP.16, para.18) konularıdır. 


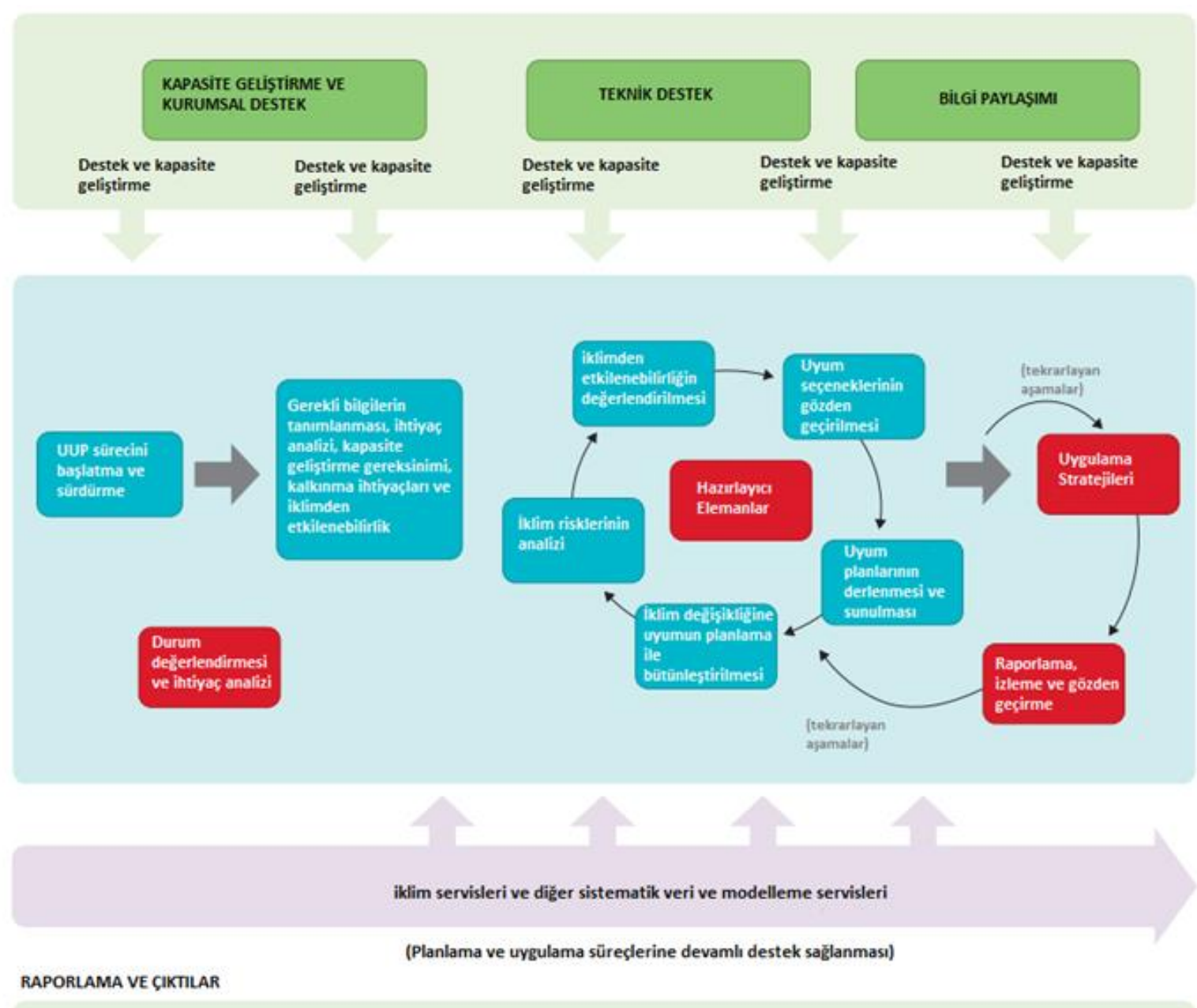

Süreç raporları, teknik raporlar, veri tabloları, strateji dokümanları, UUP, programlar vb.

Şekil 5. UUP Süreci (UNFCCC, 2019).

Esasen Kankun Kararlarının 14. Paragrafında BMIDÇS'ye taraf olan bütün ülkeler Kankun Uyum Çerçevesi altında uyuma ilișkin eylemlerini geliştirmeye davet edilmişlerdir. Bunu gerçekleștirirken ortak fakat farklılaştırılmıș sorumluluklar ve göreli kapasite prensibinin ve özel ulusal ve bölgesel gelişme önceliklerinin, hedef ve koşullarının göz önünde bulundurulması talep edilmiştir (UNFCCC, 2010).

Söz konusu kararda da vurgulandığı üzere Taraflar Konferansı, BMIDÇS’nin yukarıda da açılkanan ve yükümlülüklere ilişkin 4. maddesi ve 1/CP16 nolu kararına atıfla 5/CP17 sayılı kararda UUP'lerin hazırlanması konusunda sadece gelișmekte olan ülkeleri değil gelișmiș ülkeleri de davet etmiştir. UUP sürecini, tarafların iklim değişikliğinin etkilerine karşı hassasiyetlerini ve iklim değişikliğinin getireceği risklerin değerlendirilmesini sağlayan bir süreç olarak nitelemiştir. Ancak gelişmişlik düzeyleri göz önüne alındığında söz konusu süreci gerçekleştirmenin özellikle EAGÜ’ler için önemli olduğu vurgulanmıştır. Söz konusu kararda esasen uyum planlamasının, sürdürülebilir kalkınma planlaması kapsamında ele alınması hususu üzerinde durulmuştur.

UUP hazırlanması süreci; ulusal önceliklere bağlı olarak sürekli güncellenmesi gereken, diğer ulusal dokümanlarla uyumlu hazırlanması gerekli olan ve ulusal strateji, plan ve sürdürülebilir kalkınma hedefleriyle de uyumlu olması beklenen bir süreçtir (5/CP17 para. 2). 5/CP.17 sayılı 
kararın 3. ve 4. paragrafı uyarınca aşağıdakileri hususları sağlayacak nitelikte zenginleștirilmesi konusunda karar alınmıştır (UNFCCC, 2011):

- BMIDÇS ile uyumlu bir biçimde gerçekleştirilmeleri,

- Hassas grupların, toplulukların ve ekosistemlerin göz önüne alınması suretiyle ülke ölçeğinde, cinsiyet duyarlı, katılımcı ve tamamen șeffaf bir yaklaşım takip edilmesi,

- Eldeki en iyi bilimsel altyapı, geleneksel ve yerel bilgi rehberliğinde, uyumu ilișkili sosyal, ekonomik ve çevresel politikalarla ve eylemlerle bütünleștiren bir bakış açısıyla cinsiyet duyarlı bir yaklaşımla gerçekleştirilmeleri,

- Didaktik olmayan, diğer taraftan da bir ülkede gerçekleştirilen faaliyetler bazında tekrarlara yol açmayan eylemlerin gerçekleştirilmesi.

UUP'ler, bu doğrultuda İU sürecinde orta ve uzun vadeli hedeflerin tespit edilerek gerçekleștirilmesi için kurgulanmaktadır. Esnek bir süreç olup, her ülkenin mevcut uyum faaliyetlerini göz önüne alarak, iklim değişikliği ile ulusal karar ve politikaların bütünleştirilmesini sağlamaktadır. UUP'ların oluşturulmasına yönelik ilk rehber 17. Taraflar Konferansı'nda kurgulanmıştır ve 5/CP.17 sayılı kararda açıklanmıştır. Bu kapsamda çalışmalar BMIDÇS Uygulama Organı (Subsidiary Body on Implementation-SBI) çatısı altında yürütülmektedir. 5/CP17 kararda Sekretarya'ya UUP rehberleri hazırlama görevi verilmiştir (UNFCCC, 2011). Söz konusu rehberin kapsamı ilgili kararın ekinde yer almıştır ve aşağıdaki dört unsuru içerecek biçimde UUP'ların geliştirilmesi için tanımlayıcı eylemleri içeren bir liste (Tablo 1) içermektedir (LDC Expert Group, 2012):

A. Mevcut şartların ortaya konulması ve boşlukların tespit edilmesi: Bu bileşen kapsamında uyum için ihtiyaçlar, imkânlar, anahtar kaynaklar ulusal bazda tespit edilir. Ulusal yönetim yapısı içinde uygun görülen bir konumda UUP sürecinin takibi için bir kurumsal yapı oluşturulur ve bu kurumsal yapı tarafından sürecin idari ve yasal ilerlemesi takip edilir.

B. Hazırlayıcı elemanlar: Bu bileşen özellikle analitik faaliyetleri içermektedir. Durum değerlendirilmesi yapılan bu kısımda örneğin, plancılar/uzmanlar tarafından oluşturulan bir komisyon geleceğe ilişkin iklim senaryolarını değerlendirerek, mevcut uyum planları üzerinden yerel politikaları da göz önünde bulundurarak ve anahtar ekonomik sektörleri de değerlendirerek bir sentez rapor hazırlarlar.

C. Uygulama stratejileri: Bu kısımda uzmanlar kimin, neyi, nasıl yapacağı üzerine yoğunlaşmaktadırlar. (B) bileşeninin ölçüt ve bilgilerini kullanarak, öncelikleri tespit eder ve faaliyetlerin sırasını tespit ederler. Kapasite geliştirme ihtiyaçlarını tespit edilerek, roller ve sorumluluklar tanımlanır ve bunların koordinasyonu sağlanır.

D. Raporlama, izleme ve gözden geçirme: Uzmanlar/plancılar tarafından UUP süreçlerini takip edebilmek için bir sistem kurulur. Gözden geçirme ve plana ilişkin raporlamalar bu aşamada gerçekleştirilmektedir. 
Tablo 1. Ulusal Uyum Planlaması Sürecinin Aşamaları (LDC Expert Group, 2012).

\begin{tabular}{|c|c|c|}
\hline AŞAMALAR & KONTROL LISTESİ & UUP ÇIKTISI \\
\hline \multicolumn{3}{|c|}{ A. Mevcut şartların ortaya konulması ve boşlukların tespit edilmesi } \\
\hline $\begin{array}{l}\text { 1. UUP sürecini } \\
\text { başlatma ve } \\
\text { sürdürme }\end{array}$ & $\begin{array}{ll} & \text { UUP sürecinin özetlenmesi- uyuma ilişkin } \\
& \text { sorunlar ve firsatlar } \\
\square & \text { Koordinasyon mekanizması } \\
\square & \text { UUP için ulusal vizyon ve yasal belgeler } \\
\square & \text { Teknik ve finansal yardıma erişim } \\
\square & \text { UUP çerçevesi/strateji ve yol haritası }\end{array}$ & $\begin{array}{ll}> & \text { UUP'ler için yasal } \\
& \text { dokümanlar } \\
>\quad & \text { IDU için çerçeve ve stratejiler } \\
>\quad & \text { UUP sürecinin eylemlerini } \\
& \text { desteklemek için projelerin } \\
& \text { fonlanması } \\
>\quad & \text { UUP süreci için yol haritası } \\
\end{array}$ \\
\hline $\begin{array}{l}\text { 2. Durum } \\
\text { değerlendirmesi: } \\
\text { iklim değişikliğinin } \\
\text { etkileri, kırılganlık ve } \\
\text { uyum konusunda } \\
\text { boşlukların ve } \\
\text { ihtiyaçların tespiti ile } \\
\text { UUP'lere uygun ortamı } \\
\text { sağlamak. }\end{array}$ & $\begin{array}{ll}\square & \text { IDU eylemlerine ilişkin mevcut durumun } \\
\text { tespiti } \\
\square \quad \text { Etkiler, kırılganlık ve uyum konusunda } \\
\text { mevcut bilgilerin birleştirilmesi } \\
\square \quad \text { Kapasite durumu analizi } \\
\square \quad \text { Engellerin analizi }\end{array}$ & 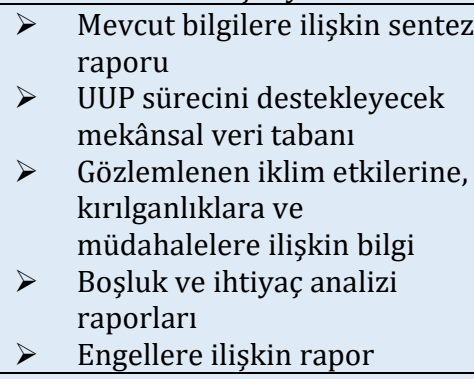 \\
\hline $\begin{array}{l}\text { 3. Kapasite } \\
\text { eksikliklerinin tespit } \\
\text { edilmesi }\end{array}$ & $\begin{array}{ll}\square & \begin{array}{l}\text { Kurumsal ve teknik kapasitenin } \\
\text { oluşturulması }\end{array} \\
\square & \text { Kalkınmayla uyumun bütünleştirilmesi } \\
\square & \text { İklim değişikliği bildirimleri, farkındalık ve } \\
& \text { eğitim programları } \\
\end{array}$ & $\begin{array}{l}\text { Kapasite geliştirme, } \\
\text { farkındalık ve eğitim için } \\
\text { strateji dokümanları } \\
\quad \text { UUP web sayfası }\end{array}$ \\
\hline $\begin{array}{l}\text { 4. Gelişme } \\
\text { ihtiyaçlarının ve } \\
\text { iklime hassasiyetin } \\
\text { değerlendirilmesi }\end{array}$ & $\begin{array}{l}\text { Gelişme hedeflerinin, politikalarının, } \\
\text { planlarının ve programlarının belirlenmesi } \\
\text { Kalkınma ve uyum hedef, plan, politika ve } \\
\text { programları arasında sinerjinin } \\
\text { sağlanması }\end{array}$ & $\begin{array}{l}\text { Kalkınma ve uyum } \\
\text { eylemlerinde mevcut durum } \\
\text { değerlendirilmesine ilişkin } \\
\text { rapor } \\
\text { Kalkınma ve uyum arasında } \\
\text { sinerjinin sağlanması } \\
\text { yaklaşımlarına ilişkin rapor }\end{array}$ \\
\hline \multicolumn{3}{|l|}{ B. Hazırlayıcı Elemanlar } \\
\hline $\begin{array}{l}\text { 1.Mevcut ve Gelecek } \\
\text { iklim değişikliği } \\
\text { senaryolarının } \\
\text { analizi }\end{array}$ & $\begin{array}{ll}\square & \text { Mevcut iklim koşullarının } \\
& \text { değerlendirilmesi } \\
\square & \text { Gelecek iklim risklerinin ve belirsizliklerin } \\
& \text { senaryo bazlı analizi } \\
\square & \begin{array}{l}\text { İklim değişikliği projeksiyonlarının } \\
\text { sunulması }\end{array} \\
\end{array}$ & $\begin{array}{ll} & \text { İklim analizi raporu } \\
>\quad & \text { İklim riskleri/ iklim } \\
& \text { değişikliği projeksiyonları } \\
& \text { raporu } \\
>\quad \text { İklim bilgisi servisleri } \\
\text { stratejisi }\end{array}$ \\
\hline $\begin{array}{l}\text { 2.İklim duyarlılığı ve } \\
\text { uyum seçeneklerinin } \\
\text { tanımlanması } \\
\text { (sektörel bazlı, ulusal, } \\
\text { bölgesel ve diğer } \\
\text { uygun ölçeklerde) }\end{array}$ & 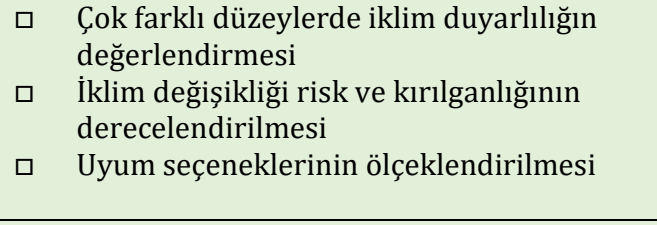 & $\begin{array}{l}\text { Duyarlıllk ve uyum } \\
\text { değerlendirme raporları }\end{array}$ \\
\hline $\begin{array}{l}\text { 3. Uyum } \\
\text { seçeneklerinin } \\
\text { gözden geçirilmesi } \\
\text { ve değerlendirilmesi }\end{array}$ & ㅁ Uyum seçeneklerinin değerlendirilmesi & $\begin{array}{l}\text { Uyum seçeneklerinin } \\
\text { değerlendirilmesine ilişkin } \\
\text { rapor } \\
>\quad \text { Sektörel ve ulus-altı ölçeğe } \\
\text { ilișkin plan ve stratejiler }\end{array}$ \\
\hline $\begin{array}{l}\text { 4. UUP'lerin tespit } \\
\text { edilmesi ve } \\
\text { bildirilmesi }\end{array}$ & $\begin{array}{ll}\square & \text { Taslak UUP'ler } \\
\square & \text { Son şeklini almış UUP'ler ve onaylama } \\
& \text { işlemleri } \\
\square & \text { Ulusal düzeyde UUP'lerin sunulması }\end{array}$ & $\begin{array}{ll}> & \text { Gözden geçirme için taslak } \\
& \text { UUP'ler } \\
>\quad \text { Onaylanmış UUP'ler }\end{array}$ \\
\hline $\begin{array}{l}\text { 5.Bütünleşik iklim } \\
\text { değişikliği } \\
\text { adaptasyonu }\end{array}$ & $\begin{array}{ll} & \text { Planlama ile iklim değişikliğinin bir arada } \\
\text { ele alınması için imkân ve sorunların } \\
\text { tespit edilmesi } \\
\square \quad \text { Bütünleştirme için kapasite gelişimi } \\
\square \quad \text { Mevcut planlama süreçleriyle uyumun } \\
\text { bütünleştirilmesi }\end{array}$ & $\begin{array}{l}\text { Kalkınma ile uyumun } \\
\text { bütünleştirilmesine ilişkin } \\
\text { rapor }\end{array}$ \\
\hline
\end{tabular}




\begin{tabular}{|c|c|c|c|c|}
\hline \multicolumn{5}{|l|}{ C. Uygulama Stratejileri } \\
\hline $\begin{array}{l}\text { 1. Ulusal planlamada } \\
\text { iklim değişikliğine } \\
\text { uyumun } \\
\text { önceliklendirilmesi }\end{array}$ & & $\begin{array}{l}\text { Önceliklendirilmiş uygulamalar için ulusal } \\
\text { ölçütlerin tespit edilmesi } \\
\text { Mevcut uyum eylemleri üzerine yeni } \\
\text { seçeneklerin tanımlanması }\end{array}$ & & $\begin{array}{l}\text { Ulusal kalkınmada uyumun } \\
\text { önceliklendirilmesine ilişkin } \\
\text { rapor }\end{array}$ \\
\hline $\begin{array}{l}\text { 2. Uzun dönemli } \\
\text { ulusal uyum } \\
\text { uygulama } \\
\text { stratejisinin } \\
\text { geliştirilmesi }\end{array}$ & & $\begin{array}{l}\text { Uyum uygulamaları için strateji } \\
\text { UUP'lerin politika, projeler ve } \\
\text { programlarla uygulanması }\end{array}$ & & $\begin{array}{l}\text { UUP'ler için uygulama } \\
\text { stratejisi }\end{array}$ \\
\hline $\begin{array}{l}\text { 3. Uyumun } \\
\text { planlanması ve } \\
\text { uygulanması için } \\
\text { kapasitenin } \\
\text { geliştirilmesi }\end{array}$ & $\square$ & $\begin{array}{l}\text { Uzun dönemli kurumsal ve yasal } \\
\text { çerçevenin güçlendirilmesi }\end{array}$ & $>$ & Ulusal eğitim programları \\
\hline $\begin{array}{l}\text { 4. Bölgesel düzeyde } \\
\text { ve diğer çok taraflı } \\
\text { çevre anlaşmaları } \\
\text { düzeyinde } \\
\text { koordinasyon ve } \\
\text { sinerjinin } \\
\text { geliştirilmesi }\end{array}$ & $\begin{array}{l}\square \\
\square \\
\square\end{array}$ & $\begin{array}{l}\text { Sektörler bazında uyum planlamasının } \\
\text { koordinasyonu } \\
\text { Bölgesel düzeyde sinerji sağlanması } \\
\text { Çok taraflı çevre anlaşmaları ile sinerji } \\
\text { sağlanması }\end{array}$ & & $\begin{array}{l}\text { Bölgesel iş birliği raporları } \\
\text { Çok taraflı çevre } \\
\text { anlaşmalarıyla uyuma ilişkin } \\
\text { raporlar }\end{array}$ \\
\hline \multicolumn{5}{|c|}{ D. Raporlama, İzleme ve Gözden Geçirme } \\
\hline $\begin{array}{l}\text { 1. İzleme ve UUP } \\
\text { süreci }\end{array}$ & $\square$ & $\begin{array}{l}\text { UUP sürecinin tanımlanarak, sürecin } \\
\text { izlenmesi, etkinliğinin ve eksikliklerin } \\
\text { tespit edilmesi. } \\
\text { Sürecin, etkinliğin ve eksikliklerin sayısal } \\
\text { olarak ifade edilerek dökümlerinin } \\
\text { alınması } \\
\text { UUP sürecine dönük bilgi toplanması }\end{array}$ & & $\begin{array}{l}\text { Ölçüm ve izleme raporları } \\
\text { Ölçüm veri tabanı }\end{array}$ \\
\hline $\begin{array}{l}\text { 2. UUP sürecinin } \\
\text { gözden geçirilerek } \\
\text { sürecin, etkinliğin ve } \\
\text { boşlukların } \\
\text { değerlendirilmesi }\end{array}$ & $\square$ & $\begin{array}{l}\text { Uyum eylemlerinin uygulanması sonucu } \\
\text { ortaya çıkan yeni değerlendirmelerin ve } \\
\text { yeni bilimsel gelişmelerin sentezi } \\
\text { Toplanan değerlendirme bilgileri ışığında } \\
\text { UUP sürecinin etkinliğinin ve } \\
\text { eksikliklerinin değerlendirilmesi }\end{array}$ & $>$ & Değerlendirme raporu \\
\hline $\begin{array}{l}\text { 3. Ulusal Uyum } \\
\text { Planlarının belli } \\
\text { periyotlarda } \\
\text { güncellenmesi }\end{array}$ & $\square$ & $\begin{array}{l}\text { UUP'lerin güncellenmesi sırasında bazı } \\
\text { aşamaların ve ilgili dokümanların } \\
\text { tekrarlanması } \\
\text { İlișkili ulusal gelişme planları ile UUP'lerin } \\
\text { çıtılarının ilişkilendirilerek güncellemeler } \\
\text { yapılması }\end{array}$ & $>$ & Güncellenmiş UUP'ler \\
\hline $\begin{array}{l}\text { 4. UUP'in } \\
\text { geliştirilmesi ve } \\
\text { sürecin etkinliğinin } \\
\text { raporlanması }\end{array}$ & & $\begin{array}{l}\text { UUP'lerin ve diğer çıktıların BMIDÇS } \\
\text { Sekretaryasına ve diğer organlara } \\
\text { iletilmesi } \\
\text { Ulusal bildirimlerde UUP sürecinin } \\
\text { etkinliğine ilişkin bilgi sağlanması }\end{array}$ & & $\begin{array}{l}\text { Ulusal bildirimlerde UUP } \\
\text { süreç raporu ve bilgisinin } \\
\text { sunulması }\end{array}$ \\
\hline
\end{tabular}

BM tarafından yukarıda temel özellikleri açılanan UUP'ların bütünleşik İDU ve ARA yaklaşımına aşağıdaki katkıları verebileceği ifade edilmektedir (UNDRR, 2020: 8);

- Ulusal politika geliştirme süreçlerinde İDU ile ARA arasındaki sinerjinin geliștirilmesi,

- Tüm risklerin kapsanabildiği tutarlı ve uyumlu bir yönetim sisteminin geliștirilmesine olanak sağlaması,

- İklim değişikliği ve doğal, biyolojik ve teknolojik kaynaklı risklerin birbirine ne şekilde bağlı olduğunun tanımlanabilmesine olanak vermesi,

- İklim değişikliyle mücadeleye ve ARA faaliyetlerine ayrılan finansman kaynaklarının daha etkin kullanımının sağlanması, 
- IDU ve ARA süreçlerinde gereksinim duyulan verilerin toplanmasının ve bu alanda yapılan çalışmalarının izlemelerinin bütünleşik yaklaşımda daha etkin bir biçimde yapılabilmesi.

BM tarafından 2020 yllında İklim ve Afet Risklerine İlişkin Bütünleştirme İş Birliği Çerçevesi (Integrating Climate and Disaster Risk in The Cooperation Framework) ortaya konulmuş ve farklı ülkelerde iklim değişikliği ve afet konularında BM kuruluşlarında çalışan BM Ülke Takımlarına rehberlik edilmesi doğrultusunda teknik kılavuzlar hazırlanmıştır. Bu kapsamda kurulması önerilen İş Birliği Çerçevesi Ulusal Takımı koordinasyonunda özetle Tablo 2'de yer verilen aşamaların gerçekleştirilmesi tavsiye edilmektedir.

Tablo 2. İDU ve ARA Eylemlerine İlişkin Bütünleştirme İş Birliği Çerçevesi Aşamaları (UNDRR, 2020: $15,16)$

\begin{tabular}{|c|c|}
\hline Aşama & Aşamalar Kapsamında Yapılması Önerilenler \\
\hline $\begin{array}{l}\text { Yol haritası } \\
\text { oluşturulması }\end{array}$ & 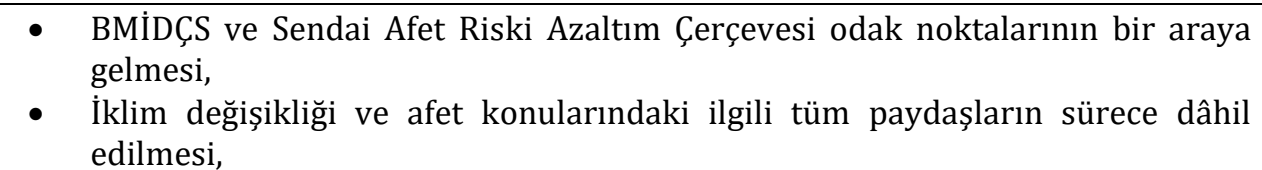 \\
\hline $\begin{array}{l}\text { Ulusal çapta } \\
\text { ortak analizler } \\
\text { yapılması }\end{array}$ & $\begin{array}{l}\text { - İklim ve afet risklerine ilişkin veri ve bilgilerin toplanması, } \\
\text { - Politika belgelerinin ve planların bir araya getirilmesi ve BM SKA'ları ile birlikte } \\
\text { değerlendirilmesi, } \\
\text { - } \quad \text { Analizler aracılığıla olası eksikliklerin, ilişskilerin ve sinerjilerin tanımlanması, } \\
\text { - CCok boyutlu risk değerlendirmelerinin yapılması, } \\
\text { - Uyum ve afetlere ilişkin eylemelere dönük kamu ve özel finansman } \\
\text { kaynaklarının değerlendirilmesi, } \\
\text { - Erken uyarı sistemlerine dönük analizler yapılması, } \\
\text { - Ekonomik dönüšume, sosyal dışlanmaya, çevreye, idari kapasiteye ve } \\
\text { yönetişim kapasitesine, insan-kalkınma- barış ilişkine yönelik analizler } \\
\text { yapılması, }\end{array}$ \\
\hline $\begin{array}{l}\text { İş birliği } \\
\text { çerçevesinin } \\
\text { tasarımı }\end{array}$ & $\begin{array}{l}\text { - Çok boyutlu risk analizleri kapsamında iklim ve afet riskleri konusunda ortak } \\
\text { bir anlayışıı oluşturulması, } \\
\text { - UUP, sağllk ve ARA planları arasında ilisskinin ve bütünlüğün sağlanması, } \\
\text { - Bu alanlarda yapılan çalışmalarda ortak çıktıların elde edilmesi ve ortak } \\
\text { - Sonuçlara ulaşılması yönünde çaba gösterilmesi, } \\
\text { - Tüm bu çalışmaların tüm paydaşları kapsayıcı bir biçimde gerçekleștirilmesi, }\end{array}$ \\
\hline $\begin{array}{l}\text { BM ülke takımı } \\
\text { oluşturulması }\end{array}$ & $\begin{array}{l}\text { - BM Kuruluşları ile iş birliği yapılabilecek alanların tanımlanması, } \\
\text { - Yeni bütünleşik iklim ve afet risk yönetimi çalışma alanlarının neler } \\
\text { olabileceğinin araştırılması, } \\
\text { - Yeni iklim projeksiyonlarının sonuçları doğrultusunda İş Birliği Takımının } \\
\text { yapısının gözden geçirilmesi, }\end{array}$ \\
\hline $\begin{array}{l}\text { Sonuçların } \\
\text { kabulü }\end{array}$ & $\begin{array}{l}\text { - Tüm bu aşamalar sonucunda elde edilecek İș Birliği Çerçevesinin afet, iklim ve } \\
\text { sağlık ile ilgili çalıșmaların paydașlarla paylașılması ve kabulü, }\end{array}$ \\
\hline $\begin{array}{l}\text { Finansman } \\
\text { sağlanması }\end{array}$ & $\begin{array}{l}\text { - Bütünleşik İDU ve ARA ve dirençliliğgin tesis edilmesine ilişkin çalışmaların } \\
\text { programlanmasında kamu ve özel sektöre ait kaynakların harekete } \\
\text { geçirilmesinde önceliklendirme yapılması, } \\
\text { Afetlerden etkilenen bireylerin söz konusu fonlara doğrudan erişiminin } \\
\text { mümkün kılınması, }\end{array}$ \\
\hline $\begin{array}{l}\text { Uygulama, } \\
\text { İzleme ve } \\
\text { Raporlama }\end{array}$ & $\begin{array}{l}\text { - Belirlenecek ölçütler aracılığıyla çalışmaların uygulamalarının izlenmesi ve } \\
\text { raporlanması } \\
\text { - Bu süreçlere de ilgili tüm paydaşların dahil edilmesi, }\end{array}$ \\
\hline Değerlendirme & $\begin{array}{l}\text { - Mevcut iklim ve afet risklerine karşı geliştirilen söz konusu İş Birliği } \\
\text { Cercevesinin genel bir değerlendirmesinin vapılmas. }\end{array}$ \\
\hline
\end{tabular}


Özetle, uluslararası alanda bütünleşik afet riski yönetimine ilişkin konular, risk arttıran bir unsur olarak giderek daha fazla şekilde iklim değişikliğiyle bir arada ele alınmaktadır. ARA ve İDU politikalarının etkin bir biçimde bütünleşik olarak ele alındığı bir yaklaşım, tehlikelere karşı hazır olmayı sağlayacağı gibi, farklı kurumlar arasında koordinasyonu ve iş birliğini kolaylaştıracak ve ayrı ayrı ele alınmaları durumunda aynı konularda tekrara düşülen çalışmaların yapılmasının önüne geçilerek, kaynak etkinliği de sağlanmış olacaktır (EEA, 2017: 15).

\section{SONUÇLAR}

Sürdürülebilir kalkınma ilkesi doğrultusunda yaşamsal süreçlerin güvenli bir biçimde devam ettirilmesinde ve toplumsal düzenin korunmasında, iklim ile ilişkili olanlar başta olmak üzere doğal, biyolojik ve insan kaynaklı tehlike ve risklerin iyi bir biçimde değerlendirilerek, bunlara yönelik kırılganlıkların azaltılması günümüzde daha da önemli hale gelmiştir. COVID-19 pandemisi, toplumu bir arada tutan unsurların nasıl da afetlerden kolayca etkilenebileceğini ve toplumların afetlere yeterince hazırlıklı olmadığını göstermesi bakımından önemlidir. İklim değişikliğinin tüm sektörleri etkileyen sonuçlarının olması, gelecekte sayı, sıklık ve şiddet bakımından artacağı öngörülen iklim ile ilişkili aşırı hava olaylarına bağlı afet risklerine karşı hazır bulunulmasını gerekli kılmaktadır.

Sürdürülebilir kalkınma ilkesinin gerçekleştirilmesi doğrultusunda günümüzde giderek daha fazla İDU ve ARA eylemlerini bütünleşik bir yaklaşımla ele almaya dönük çalışmalar yapılmaya başlanmıştır. Bu kapsamda politika geliştirme süreçlerinde ilişki kurulması önemli görülen BM sözleşmeleri ve belgeleri ise BMIDÇS ve Paris İklim Anlaşması, Sendai Afet Riski Azaltım Çerçevesi, BM 2030 Gündemi SKA'ları ve BM Habitat Yeni Kentsel Gündem'dir. Bu sayede hem bu belgeler arasında sinerjinin sağlanması hem kıt kaynakların etkin kullanımı hem de toplumun tüm kesimleri için farklı alanlarda dirençlilik sağlanması mümkün olabilecektir. Söz konusu ilişkiyi sağlamada ekosistemler ve dirençlilik konuları ortak temayı oluştururken, çalışma ölçeklerinin de ortak olmasıyla farklı paydaşlar arasında iş birliği ve koordinasyonun sağlanması da daha kolay olabilecektir. Ayrıca her iki yaklaşımın da hedef kitlesinin özellikle kırılgan toplum kesimleri olması, ARA ve IDU eylemleri arasında söz konusu bütünleşik yaklaşım sürecinin gerçekleştirilmesini hızlandırıcı bir etki oluşturacaktır.

Ancak yine de bu yaklaşımın geliştirilmesinde karşılaşılan bazı problemler de söz konusudur. Pek çok ülkede ARA ve İDU konusunda çalışan kurumlar farklıdır ve aralarında koordinasyon eksiklikleri olabilmektedir. Ayrıca bütünleşik ARA ve İDU çalışmalarında ihtiyaç duyulan verilerin eksikliği de söz konusu olabilmektedir. Bunlara ek olarak bu çalışmaların yapılabilmesi için ihtiyaç duyulan finansman ve teknik desteklere erişimde güçlükler de yaşanabilmektedir.

$\mathrm{Bu}$ zorlukların üstesinden gelinmesi ve sürdürülebilir kalkınma doğrultusunda ARA ve İDU eylemlerinin bütünleşik olarak ele alınmasında BM tarafından UUP'lar önemli bir fırsat olarak ele alınmaktadır. UUP'lar kapsamındaki aşamalar aracılığıyla, kırılganlıkların analiz edilmesi, eldeki kaynakların tespit edilmesi, plan ve politika araçlarının geliştirilmesi ve dirençliliğin artırılması mümkün olabilmektedir. Bu kapsamda kamu ve özel sektör yatırımlarının ve fonlarının söz konusu bütünleşmeyi sağlamaya dönük plan, proje ve uygulamalara öncelikle aktarılması elzemdir.

Türkiye'de de bu yaklaşım çerçevesinde önemli çalışmaların ve projelerin gerçekleștirilmeye başlandığı görülmektedir. Bu kapsamda merkezi yönetim tarafından Avrupa Birliği (AB) Katılım Öncesi Mali Yardım Aracı (The Instrument for Pre-accession Assistance-IPA) fonlarından da yararlanılarak gerçekleştirilen en güncel projelerden biri Afet ve Acil Durum Yönetimi Başkanlığı (AFAD) tarafından Türkiye'de İklim Değișikliğinden Kaynaklanan Afet Risklerinin Azaltılması ve Adaptasyonunda AFAD'ın Kapasitesinin Arttırılması için Teknik Destek Projesi'dir. Proje ile pilot illerde yerel afet eylem planları yapılması, iklim risklerine karşı kapasitenin ve farkındalığın geliştirilmesi amaçlanmaktadır (ÇŞB, 2020a). 
Ayrıca yerel ölçekte iklim değisşikliğine uyumun güçlendirilmesi yoluyla toplumsal direncin artırılması amacıyla Türkiye'de İklim Değişikliğine Uyum Eyleminin Güçlendirilmesi projesi de AB IPA fonlarından yararlanılarak Çevre ve Şehircilik Bakanlığı tarafından UNDP ile birlikte yürütülmekte ve coğrafi bölgelerde etki ve etkilenebilirlik analizlerinin yapılması hedeflenmektedir. Proje kapsamında ayrıca 2011 yılında yayımlanan Türkiye İklim Değişikliğine Uyum Stratejisi ve Eylem Planı'nı da güncellenecektir (ÇŞB, 2020b).

ARA ve İDU faaliyetlerinin bütünleşik kapsamda ele alınmasında ulusal ölçeğin yanı sıra bölge ve kent ölçeklerinde de değerlendirmeler yapılması önemlidir. Bu doğrultuda günümüzde ele alınan en önemli yaklaşımlardan biri de doğa temelli çözümlerdir. Çevre ve Şehircilik Bakanlığı ile UNDP tarafından İklim Sözü (Climate Promise) Programı çerçevesinde İDU ve ARA faydası çerçevesinde Bölgesel Doğa Temelli Çözümler Katalogları hazırlanmaktadır. Ayrıca Çevre ve Şehircilik Bakanlığı tarafından 11. Kalkınma Planı (2019-2023) kapsamında yer alan İDU ve ARA konuları doğrultusunda bölgesel etki ve kırılganlıkların ortaya konulması hedefinin gerçekleştirilmesine dönük olarak yedi coğrafi bölge için Bölgesel İklim Değişikliği Eylem Planlarının hazırlandığı açıklanmıştır. Bakanlık tarafından kent ölçeğinde sera gazı azaltımı, uyum ve dirençlilik bağlamında öncelikli eylemlerin belirlenerek uygulanabilmesi için Yerel İklim Değişikliği Eylem Planları'nın hazırlanmasına dönük mevzuat ve teknik kılavuz çalışmalarının da sürdürüldügü açıklanmıştır (ÇŞB, 2021).

Afetlere karşı dirençliliğin sağlanması, özellikle iklim ile ilişkili risklere karşı önlem alınması ve toplumsal hassas kesimler başta olmak üzere tüm toplumun ve ekosistemlerin korunması doğrultusundaki çabalarda, yerel, ulusal ve uluslararası tüm paydaşların iş birliği içinde çalışması söz konusu çabaların başarısını belirleyen önemli bir husustur.

\section{KAYNAKLAR}

Anzellini, V., B. Desai ve C. Leduc (2020). Grid 2020 Global Report on Internal Displacement. Geneva: IDMC.

Birkmann, Jörn ve Von Teichman, K. (2010). Integrating Disaster Risk Reduction and Climate Change Adaptation: Key Challenges-Scales, Knowledge, and Norms, Sustainability Science, 5(2):171-184.

Busayo, E. T. ve Kalumba, A. M. (2020). Coastal Climate Change Adaptation and Disaster Risk Reduction: A Review of Policy, Programme and Practice for Sustainable Planning Outcomes, MDPI-Sustainability, 12 (16): 1-16.

ÇŞB. (2020a). Türkiye'de İklim Değişikliğinden Kaynaklanan Afet Risklerinin Azaltılması ve Adaptasyonunda AFAD'ın Kapasitesinin Arttırılması için Teknik Destek Projesi, https://ipa.gov.tr/HaberDetay/IPA-II-Donemi-\%E2\%80\%9C-Turkiye\%27de-Iklim-DegisikligindenKaynaklanan-Afet-Risklerinin_2279 (Erişim Tarihi: 13.05.2021).

ÇŞB. (2020b). Türkiye'de İklim Uyum Eyleminin Güçlendirilmesi Projesinin Açılışı Gerçekleștirildi, https://ipa.gov.tr/HaberDetay/Turkiye\%E2\%80\%99de-Iklim-Uyum-Eyleminin-Guclendirilmesi-

Projesinin-Acilisi-Gerceklestirildi_2269 (Erişim Tarihi: 13.05.2021).

ÇŞB. (2021). Bakan Kurum: “ïklim Değişikliğiyle Mücadele Raporunu Meclise Sunacağız", https://csb.gov.tr/bakan-kurum-iklim-degisikligiyle-mucadele-raporunu-meclise-sunacagiz-bakanlikfaaliyetleri-30881 (Erişim Tarihi: 13.05.2021).

Davies, M., Guenther, B., Leavy, J., Mitchell, T. ve Tanner, T. (2009). Climate Change Adaptation, Disaster Risk Reduction and Social Protection: Complementary Roles in Agriculture and Rural Growth?, IDS Working Papers, 2009 (320): 1-37. 
EEA. (2017). Climate change adaptation and disaster risk reduction in Europe-Enhancing coherence of the knowledge base, policies and practices. EEA Report No 15/2017, Luxembourg: Publications Office of the European Union.

Forino, G., Von Meding, J., Brewer, G. ve Gajendran, T. (2014). Disaster Risk Reduction and Climate Change Adaptation Policy in Australia Procedia Economics and Finance, 18 (2014) 473-482.

Guralnick, J. (2018). The Sendai Framework for Disaster Risk Reduction 2015-2030: A Tool for Adaptation to Climate Change and National Adaptation Plans, http://comunidadpnacc.com/wpcontent/uploads/2019/04/Integrating_DRM_ACC_and_SDG.pdf (Erişim Tarihi: 13.12.2020)

IOM (2010). Disaster Risk Reduction, Climate Change Adaptation and Environmental Migration: A Policy Perspective, https://publications.iom.int/system/files/pdf/ddr_cca_report.pdf (Erişim Tarihi: 13.12.2020)

IPCC (2012). Managing the Risks of Extreme Events and Disasters to Advance Climate Change Adaptation. Special Report of the Intergovernmental Panel on Climate Change. Summary for policymakers, Cambridge University Press.

IPCC (2014a). AR5 Report, Working Group II: Climate Change: Impacts, Adaptation and Vulnerability, Summary for Policy Makers, IPCC.

IPCC (2014b). Climate Change 2014 Synthesis Report, Contribution of Working Groups I, II and III to the Fifth Assessment Report of the Intergovernmental Panel on Climate Change, Geneva: IPCC.

IPCC (2018a). Special Report: Global Warming of 1.5 OC, IPCC.

IPCC (2018b). Annex I: Glossary (Ed. Robin Matthews), Global Warming of $1.5^{\circ} \mathrm{C}$. An IPCC Special Report, IPCC.

Islam, S., Cordia, C., Smart, J. C. R. ve Liew, L. (2019). Integrating Disaster Risk Reduction and Climate Change Adaptation: A Systematic Literature Review, Climate and Development, 12(3): 255-267.

Least Developed Countries Expert Group. 2012. National Adaptation Plans. Technical Guidelines for the National Adaptation Plan Process. Bonn: UNFCCC Secretariat.

Lisa, E. ve Schipper, F. (2011). Meeting at The Crossroads?: Exploring The Linkages Between Climate Change Adaptation and Disaster Risk Reduction, Climate and Development, 1(1): 16-30.

Mercer, J. (2010). Disaster Risk Reduction or Climate Change Adaptation: Are We Reinventing The Wheel?, Journal of International Development, 22 (2): 247-264.

Munang, R., Thiaw, I., Alverson, K., Liu, J. ve Han, Z. (2013). The Role of Ecosystem Services in Climate Change Adaptation and Disaster Risk Reduction, Sustainability, 5 (1): 47-52.

NAP Community (2019). The Sendai Framework for Disaster Risk Reduction 2015-2030: A tool for Adaptation to Climate Change and National Adaptation Plans, http://comunidadpnacc.com/en/the-sendaiframework-for-disaster-risk-reduction-2015-2030-a-tool-for-adaptation-to-climate-change-and-nationaladaptation-plans/ (Erişim Tarihi: 13.12.2020)

Prasad, N., Ranghieri, F., Trohanis, F. S., Kessler, E. ve Sinha, R. (2009). Climate Resilient Cities: A Primer on Reducing Vulnerabilities to Disasters, Washington: World Bank.

Santoalla, E. (2010). Integrating Disaster Risk Reduction and Climate Change Adaptation in the Philippines, Quezon City, Phillipines: Oxfam.

Solecki, W., Leichenko, R. ve O’Brien (2011). Climate Change Adaptation Strategies and Disaster Risk Reduction in Cities: Connections, Contentions, and Synergies, Sustainability, 3 (3): 135-141. 
Thomalla, F., Downing, T., Spanger-Siegfried, E., Han, G. ve Rockström, J. (2006). Reducing Hazard Vulnerability: Towards a Common Approach Between Disaster Risk Reduction and Climate Adaptation, Disasters, 30 (1): 39-48.

The Cities Alliance, ICLEI ve UNEP (2007). Livable Cities the Benefits Of Urban Environmental Planning: A Cities Alliance Study On Good Practices And Useful Tools, Washington: The Cities Alliance.

UN (1996). Recife Declaration: "Urban Poverty: A World Challenge" Habitat II Recife International Meeting on Poverty, Recife, Brazil.

UN (2021). Sustainable Development Goals, https://sdgs.un.org/ (Son Erişim Tarihi: 07.02.2021)

UNDP (2020a). BM SKA1: Yoksulluğa Son, ttps://www.tr.undp.org/content/turkey/tr/home/sustainabledevelopment-goals/goal-1-no-poverty.html (Erişim Tarihi: 27.11.2020)

UNDP (2020b). Sürdürülebilir Kalkınma Amaçları Nelerdir? https://www.tr.undp.org/content/turkey/tr/home/sustainable-development-goals.html (Son Erişim Tarihi: 17.12 .2020$)$

UNDRR (2015). The Sendai Framework for Disaster Risk Reduction 2015-2030, UN General Assembly Resolution A/RES/69/283, UN.

UNDRR (2020). Integrating Disaster Risk Reduction and Climate Change Adaptation in the UN Sustainable Development Cooperation Framework: Guidance Note on Using Climate and Disaster Risk Management to Help Build Resilient Societies, Geneva: UNDRR.

UNDRR ve CRED (2020). The Human Cost of Disasters: An Overview of the Last 20 Years (2000-2019), UNDRR.

UNFCCC (1992). United Nations Framework Convention on Climate Change, UN.

UNFCCC (2010). Decision 1/CP.16 The Cancun Agreements, https://unfccc.int/resource/docs/2010/cop16/eng/07a01.pdf (Erişim Tarihi: 12.02.2021)

UNFCCC (2011). Decision 5/CP.17: National Adaptation Plans, https://unfccc.int/files/adaptation/cancun_adaptation_framework/national_adaptation_plans/applicatio n/pdf/decision_5_cp_17.pdf (Son Erişim Tarihi: 17.12.2020).

UNFCCC (2015). Paris Agreement, Paris: UN.

UNFCCC (2019). Current Progress on 2019, http://napexpo.org/napblogger/our_blog/progressonnapsjune2019/ (Son Erişim Tarihi: 17.12.2020)

UNFCCC (2017). Opportunities and Options for Integrating Climate Change Adaptation with the Sustainable Development Goals and the Sendai Framework for Disaster Risk Reduction 2015-2030, Bonn: UNFCCC.

UNFCCC (2021). UNFCCC Technical Guidelines for the NAP Process, https://www4.unfccc.int/sites/NAPC/Guidelines/Pages/Technical-guidelines.aspx (Son Erişim Tarihi: 12.02.2021)

UN Habitat (2016). New Urban Agenda, UN Habitat.

UN Habitat (2020). Status of Human Settlements Statistics, UN Habitat Publication.

UNICEF ve AIDMI (2016). Integration of Disaster Risk Reduction and Climate Change Adaption for Sustainable Development, https://www.preventionweb.net/files/51048_51034policybriefdrrandcca.pdf (Son Erişim Tarihi: 17.12.2020) 
Warner, K., Ranger, N., Surminski, S., Arnold, M., Linnerooth, J., Michel-Kerjan, E., Kovacs, P. Ve Herweijer, C. (2009). Adaptation to Climate Change: Linking Disaster Risk Reduction and Insurance, Geneva: UNISDR.

WEF (2021). The Global Risks Report 2021, Geneva: WEF.

World Bank (2020). Poverty and Shared Prosperity 2020 Reversals of Fortune. Washington: World Bank. 